CONCISE REPORT

\title{
Prevalence of the antiphospholipid syndrome in primary systemic vasculitis
}

\author{
J D Rees, S Lança, P V Marques, J A Gómez-Puerta, R Moco, C Oliveri, M A Khamashta, \\ G R V Hughes, D P D'Cruz
}

Ann Rheum Dis 2006;65:109-111. doi: 10.1136/ard.2004.034231

\begin{abstract}
Background: The antiphospholipid (APS or Hughes') syndrome, anticardiolipin antibodies (aCL), and the lupus anticoagulant (LA) are associated with systemic lupus erythematosus, malignancy, infection, and drugs. It has been described in patients with primary systemic vasculitis (PSV).

Objective: To determine the prevalence of APS in patients with PSV attending a vasculitis clinic and the prevalence of patients with positive aCL and/or the LA who do not fulfil the classification criteria for APS.

Methods: All case notes of patients attending the vasculitis clinic over a 12 month period were reviewed. Outpatients and inpatients were both included and were assessed for features of the APS and presence of aPL. Patients with positive $\mathrm{aCL}$ or $\mathrm{LA}$ tests were classified according to the significance of these results.

Results: Of 144 patients with PSV, 25 had positive $\mathrm{aCL}$ or LA on at least one occasion, representing a point prevalence of $17 \%$. Of these, nine had definite APS (classified by the Sapporo criteria) and a further four patients had clinical and serological features of APS, although insufficient to satisfy the Sapporo criteria. Twelve had only positive aPL.

Conclusion: The antiphospholipid syndrome, $\mathrm{aCL}$, and the LA may occur in association with PSV.
\end{abstract}

$\mathrm{T}$ he antiphospholipid syndrome (APS or Hughes' syndrome) is associated with systemic lupus erythematosus and other connective tissue diseases, malignancy, infection, and drug induced syndromes. Antiphospholipid antibodies (aPL) and thrombosis may also occur in patients with primary systemic vasculitis (PSV). Several case reports have described APS in individual patients with polyarteritis nodosa, ${ }^{1-4}$ microscopic polyangiitis, ${ }^{5}$ and, in particular, Wegener's granulomatosis. ${ }^{6}$ Other reports describe several patients with giant cell arteritis/polymyalgia rheumatica and $\mathrm{APS}^{7-9}$ or Behçet's disease and APS. ${ }^{10}$ More recently, a high prevalence of aPL has been reported in different vasculitides, including Takayasu's arteritis. ${ }^{11}$ However, one prospective study failed to find an increased prevalence of aPL in the systemic vasculitides in comparison with healthy blood donors, though the number of patients studied was small. ${ }^{12}$ A further large study of 1000 consecutive patients with APS found only a very small proportion $(0.7 \%)$ had a diagnosis of systemic vasculitis. ${ }^{13}$

Our experience of patients with PSV suggested that a significant number of these patients have a prothrombotic tendency. We therefore set out to assess the prevalence and clinical associations of aPL in a cohort of current inpatient and clinic attendees over a 12 month period.

\section{METHODS}

All attendees at the vasculitis clinic at St Thomas' Hospital over the 12 month period October 2001-October 2002 were reviewed. We also included all inpatients admitted under our care during this time. The case notes were reviewed and only those patients with a definite diagnosis of PSV were included. Patients in whom a diagnosis of systemic lupus erythematosus was suspected were excluded. The 144 patients were classified according to American College of Rheumatology (ACR) criteria ${ }^{14}$ and for those with microscopic polyangiitis according to the Chapel Hill consensus definition..$^{15}$ Patients not meeting these criteria were designated unclassified systemic vasculitis.

All patients were tested for anticardiolipin antibodies (aCL) and lupus anticoagulant (LA) on at least one occasion. The following information was recorded: $(a)$ diagnosis; $(b)$ age and sex; (c) aCL and LA status; $(d)$ clinical features of APS (for example, thrombosis, recurrent fetal loss, florid livedo reticularis, thrombocytopenia). Patients' results were classified as follows: (a) classical APS - fully met international consensus (Sapporo) criteria for definite APS ${ }^{16} ;(b)$ possible APS - patients with positive serology (aCL and/or LA) and some clinical features of APS but not enough to fulfil the Sapporo criteria; (c) positive serology only-no clinical features but presence of aCL and/or LA; (d) negative-no features of APS; (e) according to the anti-thrombotic treatment that had been instituted (none/low dose aspirin alone/formal anticoagulation).

The aCL and LA were detected by standard methods in our laboratory. ${ }^{17} 18$ Patients with positive aPL were classified according to the significance of these results. Those who met the international consensus criteria were classified as having definite APS. Those who had clinical features of APS with positive aCL or LA serology but not fulfilling the international criteria were classified as possible APS.

\section{RESULTS}

One hundred and forty four patients (53 male, 91 female) attending the vasculitis clinic were included in the study. Their median age was 54 years (range 18-91). Of the 144 patients, 89 were classified according to the ACR criteria and a further patient was diagnosed with microscopic polyangiitis under the Chapel Hill Consensus definition. Patients classified according to the ACR criteria included: 42 with Wegener's granulomatosis, 18 Churg-Strauss syndrome, 14 polyarteritis nodosa, 6 Henoch-Schönlein purpura, 6 giant cell arteritis, and 3 Takayasu's arteritis. Eighteen were classified clinically as follows: cutaneous vasculitis (9 patients), vasculitis of the central nervous system (3

Abbreviations: aCL, anticardiolipin antibodies; $\mathrm{ACR}, \mathrm{American}$ College of Rheumatology; aPL, antiphospholipid antibodies; APS, antiphospholipid syndrome; LA, lupus anticoagulant; PSV, primary systemic vasculitis 
Table 1 Summary of patients with systemic vasculitis who also had a definite (Sapporo criteria) diagnosis of antiphospholipid syndrome

\begin{tabular}{|c|c|c|c|c|c|c|c|}
\hline 1 & 64 & M & Polyarteritis nodosa & $\begin{array}{l}\lg \mathrm{A}>160 \mathrm{U} / \mathrm{ml} \\
\text { multiple occasions }\end{array}$ & - & Multiple venous thrombotic events & Lifelong warfarin \\
\hline 2 & 52 & $\mathrm{~F}$ & Relapsing polychondritis & $\begin{array}{l}\mathrm{lgG}>16 \mathrm{U} / \mathrm{ml} \\
\text { multiple occasions }\end{array}$ & - & $\begin{array}{l}\text { Bilateral deep vein thromboses (no } \\
\text { other cause found) }\end{array}$ & Lifelong warfarin \\
\hline 3 & 56 & M & $\begin{array}{l}\text { Wegener's } \\
\text { granulomatosis }\end{array}$ & $\mathrm{lg} M$ up to $70 \mathrm{lU} / \mathrm{ml}$ & - & DVT $\times 1$ (no other cause found) & Lifelong warfarin \\
\hline 4 & 56 & $\mathrm{~F}$ & $\begin{array}{l}\text { Churg-Strauss } \\
\text { syndrome }\end{array}$ & $\begin{array}{l}\text { multiple occasions } \\
\text { - }\end{array}$ & $\begin{array}{l}\text { Multiple } \\
\text { positives }\end{array}$ & $\begin{array}{l}\text { Thrombotic CVA (no other cause } \\
\text { found) }\end{array}$ & Lifelong warfarin \\
\hline 5 & 64 & M & $\begin{array}{l}\text { Unclassified systemic } \\
\text { disease }\end{array}$ & $\lg G \times 2$ & - & DVT and PE & $\begin{array}{l}\text { Started warfarin, died on } \\
\text { ITU }\end{array}$ \\
\hline 6 & 71 & $\mathrm{~F}$ & $\begin{array}{l}\text { Giant cell arteritis } \\
(29 \mu / \mathrm{ml}, 17 \mu / \mathrm{ml})\end{array}$ & $\lg M \times 2$ & - & Thrombotic CVA & Lifelong warfarin \\
\hline 7 & 60 & $\mathrm{~F}$ & $\begin{array}{l}\text { Churg-Strauss } \\
\text { syndrome }\end{array}$ & - & $\begin{array}{l}\text { Multiple } \\
\text { positives }\end{array}$ & Thrombotic CVA & Lifelong warfarin \\
\hline 8 & 55 & M & $\begin{array}{l}\text { Limited Wegener's } \\
\text { granulomatosis }\end{array}$ & $\lg M>17 \mathrm{U} / \mathrm{ml}$ & - & $\begin{array}{l}\text { Thrombotic microangiopathy on } \\
\text { renal biopsy }\end{array}$ & \\
\hline 9 & 39 & $\mathrm{~F}$ & Takayasu's disease & $\lg G 10.4 \mathrm{U} / \mathrm{ml}$ & $\begin{array}{l}\text { Multiple } \\
\text { positives }\end{array}$ & $\begin{array}{l}\text { recurrent abortions (4) and one } \\
\text { intrauterine death }\end{array}$ & Aspirin 75 mg daily \\
\hline
\end{tabular}

patients), mesenteric vasculitis (2 patients), cryoglobulinaemic vasculitis ( 2 patients), relapsing polychondritis (1 patient), and retinal vasculitis ( 1 patient). A further 36 patients with vasculitis remained unclassified.

The average age at diagnosis was 45 and the average treatment duration was 8 years. Vasculitis Damage Index (VDI) scores were available for $135 / 144$ patients. The mean (SD) VDI at diagnosis was 2.13 (1.71) and at the last follow up was $2.72(2.18)$. Of the 42 patients with Wegener's granulomatosis, half had localised and half generalised disease. Of the Wegener's group overall, 34 required treatment with cyclophosphamide at presentation while a further 3 required cyclophosphamide subsequently.

Of these 144 patients, 25 (17\%) had some features of the APS: $9(6 \%)$ had classical APS by Sapporo criteria while 4 had features of APS with positive serology but not enough for the Sapporo criteria (probable or possible APS). A further 12 had positive aPL serology with no significant clinical features; the remaining 119 were completely negative for aPL. Table 1 summarises the patients with definite APS. Of the 12 patients with positive aPL but without clinical features of APS, one had positive serology for both aCL and LA, four were positive for aCL alone, and the remaining seven were LA positive. Of the seven positive for LA alone, four were positive on multiple occasions.

\section{DISCUSSION}

Our results show a prevalence of definite APS of 6\% (9/144) in our population of patients with PSV. A further 3\% (4/144) have features (both clinical and serological) of APS and we have classified these as possible APS. Additionally, 8\% (12/ 144) have positive serology for aCL or LA, or both.

As this series is retrospective it is subject to possible left censorship bias in that some patients may have died during the 12 month collection period. We made every effort to include patients who had died and although two patients did die during this period, (definite APS patient 5 and a further patient who was aPL and LA negative) this did not significantly affect our results.

The nine patients with definite APS demonstrate that the APS may occur in association with a PSV, complicating clinical management for these cases. Six of the 12 patients with serological features of APS had persistently positive serology. Of note, although Behçet's disease was included in our cohort of patients with vasculitis, none of these patients had a thrombosis or positive serology at any time.
It has been suggested that aPL are associated with acute vascular inflammation, ${ }^{19}$ and their temporary presence in the serum is a reflection of polyclonal globulin secretion. Thus, their presence in vasculitis may simply represent a secondary response. Another hypothesis is that the endothelial cell disruption which occurs in vasculitis reveals cryptic antigens and stimulates antiendothelial cell antibodies that may be part of the spectrum of aPL. ${ }^{20}$ In this case, aPL might just be an epiphenomenon of endothelial phospholipid exposure due to vascular inflammation, as proposed by Manna et al. ${ }^{7}$ Some authors found positive aPL in patients with acute infections such as mycoplasma, adenovirus, rubella, chicken pox, and mumps. ${ }^{21}$ The levels often declined when the infection resolved, were often low, and not associated with thrombosis. This possibility might explain the presence of aPL in some of our patients; particularly the patients with only one weak positive result. However, many of our patients had high titre positive antibody levels which were consistently present over time. Only one patient (patient No 5 with definite APS) had a well demonstrated infection at the time of aPL testing.

Our series of patients highlight the fact that some patients appear to have highly pathogenic LA or aCL and thrombosis while other patients, often with high antibody titre levels, do not. Possibly, the pathogenicity of the antibodies is influenced by host genetic factors, antibody isotype, and underlying vessel wall integrity, as proposed by Norden et al. ${ }^{19}$

In conclusion, our data suggest that aPL can be present in patients with PSV and may influence its clinical course and management. Studies are in progress to assess the possible impact of aPL on morbidity in these patients.

\section{Authors' affiliations}

J D Rees, S Lança, P V Marques, J A Gómez-Puerta, R Moco, C Oliveri, M A Khamashta, G R V Hughes, D P D'Cruz, The Lupus Research Unit, The Rayne Institute, St Thomas' Hospital, London, UK

Correspondence to: Dr David D'Cruz, The Lupus Research Unit, The Rayne Institute, St Thomas' Hospital, London SE1 7EH, UK; david.d'cruz@kcl.ac.uk

Accepted 27 May 2005

\section{REFERENCES}

1 Fernandez RLF, Gil JG. Anticardiolipin antibodies and polyarteritis nodosa. Lupus 1994;3:523-4. 
2 Cohney S, Saviage J, Stewart MR. Lupus anticoagulant in anti-neutrophil cytoplasmic antibody-associated polyarteritis. Am J Nephrol 1995; 15:157-60.

3 Dasgupta B, Almond MK T. Polyarteritis nodosa and the antiphospholipid syndrome. Br J Rheumatol 1997;36:1210-12.

4 Morelli S, Perrone C, Paroli M. Recurrent cerebral infarctions in polyarteritis nodosa with circulating antiphospholipid antibodies and mitral valve disease. Lupus 1998;7:51-2.

5 Handa R, Aggarwal P, Biswas A, Wig N, Wali JP. Microscopic polyangiitis associated with antiphospholipid syndrome. Rheumatology (Oxford) 1999;38:478-9.

6 Castellino G, La Corte R, Santilli D, Trotta F. Wegener's granulomatosis associated with antiphospholipid syndrome. Lupus 2000;9:717-20.

7 Manna R, Latteri M, Cristiano G, Todaro L, Scuderi F, Gasbarrini G. Anticardiolipin antibodies in giant cell arteritis and polymyalgia rheumatica: a study of 40 cases. Br J Rheumatol 1998;37:208-10.

8 Seriolo B, Cutolo M, Garnero A, Accardo S. Risk factors for thrombotic events in giant cell arteritis and polymyalgia rheumatica. $\mathrm{Br} J$ Rheumatol 1998; $37: 1251-3$

9 Ruffatti A, Montecucco C, Volante D, Del Ross T, Sartori T, Rapizzi E, et al. Antiphospholipid syndrome and polymyalgia rheumatica/giant cell arteritis. Rheumatology (Oxford) 2000;39:565-7.

10 Hull R, Harris E, Gharavi A, Tincani A, Asherson RA, Valesini G, et al. Anticardiolipin antibodies: occurrence in Behçet's syndrome. Ann Rheum Dis 1984;43:746-8.

11 Baranov A, Kirdianov S, Nasonov E, Beketova T, Gurieva M, Bashina O, et al Antibodies to anticardiolipin and $\beta 2 \mathrm{GP} 1$ in systemic vasculitis and primary antiphospholipid syndrome. J Rheumatol 2001;28(suppl):5(T59).
12 Merkel P, Chang Y, Pierangeli S, Convery K, Harris EN, Polisson RP. The prevalence and clinical associations of anticardiolipin antibodies in a large inception cohort of patients with connective tissue diseases. Am J Med 1996;101:576-83.

13 Cervera R, Piette JC, Font J, Khamashta MA, Shoenfeld Y, Camps MT, et al. Antiphospholipid syndrome. The clinical and immunogenic manifestations and patterns of disease expression in a cohort of 1,000 patients. Arthritis Rheum 2002;46: 1019-27.

14 Hunder GG, Arend WP, Bloch DA, Calabrese LH, Fauci AS, Fries JF, et al. The American College of Rheumatology 1990 criteria for the classification of vasculitis:introduction. Arthritis Rheum 1990;33:1065-7.

15 Jenette JC, Falk RJ, Andrassy K, Bacon PA, Churg J, Gross WL, et al. Nomenclature of systemic vasculitidies. Proposal of an international consensus conference. Arthritis Rheum 1994;37:187-92.

16 Wilson WA, Gharavi AE, Koike T, Lockshin MD, Branch DW, Piette JC, et al. International consensus statement on preliminary classification criteria for definite antiphospholipid syndrome. Arthritis Rheum, 1999;42;1309-11.

17 Harris EN, Chan JKN, Asherson RA, Aber VR, Gharavi AE, Hughes GRV. Thrombosis, recurrent fetal loss and thronbocytopenia. Predictive value of the anticardiolipin antibody test. Arch Intern Med 1986;146:2153-6.

18 Brandt JT, Triplett DA, Alving B, Scharrer I. Criteria for the diagnosis of lupus anticoagulants: an update. Throm Haemost 1995;74:1185-90.

19 Norden DK, Ostrov BE, Shafritz AB, Von Feldt JM. Vasculitis associated with antiphospholipid syndrome. Semin Arthritis Rheum 1995;24:273-81.

20 Baguley E, Hughes GRV. Antiendothelial cell antibodies. J Rheumatol 1989;16:716-17.

21 Vaarala O, Palosuo T, Kleemola M, Aho K. Anticardiolipin response in acute infections. Clin Immunol Immunopathol 1986;41:8-15. 